\title{
PARTNERSTWO PUBLICZNO-PRYWATNE JAKO FORMA ŚWIADCZENIA USŁUG PUBLICZNYCH Z ZAKRESU OŚWIATY
}

\section{Wprowadzenie}

Celem artykułu jest prezentacja idei partnerstwa publiczno-prywatnego jako jednego ze sposobów świadczenia usług publicznych w dziedzinie oświaty. Partnerstwo publiczno-prywatne wpisuje się w nurty zarządzania sprawami publicznymi, inspirowane neoliberalną myślą ekonomiczną, określane jako New Public Management i New Governance, zakładające szeroki udział sektora pozarządowego i prywatnego w produkcji i dystrybucji dóbr publicznych. Udział ten manifestuje się bądź $\mathrm{w}$ realizacji przez podmioty spoza administracji publicznej projektów "twardych" dotyczących inwestycji infrastrukturalnych, bądź w wykonywaniu zadań „miękkich”, z zakresu świadczenia usług edukacyjnych (prowadzenia kształcenia lub szkolenia).

Model zaangażowania podmiotów prywatnych w budowę, a następnie wieloletnie zarządzanie szkołami najpełniej rozwinął się w Wielkiej Brytanii w postaci tzw. instrumentu Private Financial Initiative. W Polsce szczególnym przykładem zastosowania formuły partnerstwa publiczno-prywatnego w oświacie jest możliwość przekazania, w drodze umowy, istniejącej szkoły samorządowej do prowadzenia osobie fizycznej lub osobie prawnej, co może być traktowane jako faktyczne współprowadzenie przez jednostkę samorządu terytorialnego szkoły wraz z podmiotem niepublicznym. Zarówno w naszym państwie, jak i w innych państwach europejskich systematycznie wzrasta liczba projektów i przedsięwzięć oświatowych angażujących wspólnie podmioty publiczne i prywatne.

* Kancelaria Prezesa Rady Ministrów.

1 Artykuł przedstawia poglądy i opinie autorki. 


\section{Idea partnerstwa publiczno-prywatnego w wykonywaniu zadań publicznych}

Partnerstwo publiczno-prywatne w oświacie ma długą tradycję. Historycznie nauczaniem zajmowały się bowiem kościoły oraz podmioty prywatne. Dopiero w XIX w. państwo i jego agendy (w tym samorząd terytorialny) zaczęło przejmować odpowiedzialność za organizację i świadczenie usług edukacyjnych, wprowadzając obowiązek szkolny, rozwijając systemy publicznego szkolnictwa finansowanego z powszechnych podatków oraz ograniczając w tej materii rolę sektora prywatnego, obywatelskiego, a nawet rodziców.

Kulminacja rozwoju państwa opiekuńczego przypadła na lata 50. i 60. XX w., niemniej od końca lat 70. państwo dobrobytu konfrontowało się z jednej strony ze wzrostem deficytu sektora finansów publicznych, a z drugiej - z narastającymi oczekiwaniami w zakresie dostępności i jakości usług publicznych. Decydenci polityczni dostrzegli zalety włączania podmiotów prywatnych w sfery aktywności zarezerwowane dla administracji publicznej. Wykorzystanie schematów zarządzania i finansowania ze środków prywatnych pozwalało także na ominięcie restrykcji związanych np. z procedurami administracyjnymi czy poziomem zadłużenia publicznego. Partnerstwo publiczno-prywatne miało być też elementem szerszej strategii zwiększania efektywności i wydajności sektora publicznego poprzez implementowanie do niego wiedzy, doświadczeń i innowacyjności sektora prywatnego ${ }^{2}$.

Wzrost zaangażowania sektora niepublicznego oraz zacieranie się granic pomiędzy sferą publiczną a prywatną wystąpiły także na polu oświaty. Nie wdając się w szczegółowe rozważania na temat natury edukacji (dobra publicznego vs. prywatnego ${ }^{3}$ ), należy zauważyć, że edukacja wywołuje efekty w sferze zbiorowej i indywidualnej Przyczynia się do osiągania rozwoju gospodarczego, dobrobytu społecznego i ładu politycznego, a zarazem przynosi indywidualne korzyści materialne i niematerialne

Ch. Hood, A public management for all seasons?, „Public Administration” Vol. 69, Spring 1991, s. 3-19.

3 Por. J.M. Fijor, Czy dobra publiczne sa naprawde publiczne?, „Studia Ekonomiczne” nr 1 (LXVIII), 2011, s. 87-100, http://www.inepan.pl/pliki/studia_ekonomiczne/Studia\%202011\%201\%205\%20fijor.pdf [dostęp 23.02.2018].

4 Por. B. Daviet, Revisiting the Principle of Education as a Public Good, Education Research and Foresight Working Papers, UNESCO, July 2016, http://unesdoc.unesco.org/images/0024/002453/245306E.pdf [dostęp 20.02.2018]. 
jednostkom i ich rodzinom ${ }^{5}$. Postrzeganie edukacji jako dobra publicznego nie wyklucza możliwości jego dostarczania przez sektor prywatny ${ }^{6}$.

W konsekwencji samo pojęcie partnerstwa publiczno-prywatnego ma wiele znaczeń, warstw i odcieni. Najogólniej PPP można zdefiniować jako bardziej lub mniej trwałą współpracę pomiędzy podmiotami publicznymi i prywatnymi, w efekcie której następuje produkcja dóbr i/lub usług oraz współdzielenie ryzyka, kosztów i korzyści Termin „partnerstwo publiczno-prywatne” obejmuje szereg zjawisk, począwszy od bezpośredniej produkcji danych dóbr (usług) przez sektor prywatny, poprzez formy kontraktowe, do mniej sformalizowanej współpracy sektora publicznego np. z instytucjami filantropijnymi czy związkami wyznaniowymi.

PPP, obok kontraktowania, zlecania i outsourcingu, często jest utożsamiane z prywatyzacją i urynkowieniem usług publicznych ${ }^{8}$. Tło ideologiczne dla realizacji projektów PPP stworzył neoliberalizm ekonomiczny oraz powiązana z nim koncepcja zarządzania sprawami publicznymi określana jako nowe zarządzanie publiczne9 Nowe zarządzanie publiczne charakteryzowało się m.in. tendencją do ograniczania roli administracji w świadczenie usług publicznych, decentralizacji, delegowania i deregulacji, prywatyzacji zadań publicznych oraz uelastyczniania i dywersyfikacji struktur organizacyjnych ${ }^{10}$.

Najpełniej PPP rozwinęło się wraz z pojawieniem się idei New Governance opartej na zasadzie partycypacyjnej i sieciowej, zakładającej zinstytucjonalizowaną współpracę wszystkich uczestników życia publicznego - polityków, organów administracji publicznej, organizacji pozarządowych, przedsiębiorców na rzecz realizacji zadań publicznych ${ }^{11}$. Organom władzy ma przypadać w tym ujęciu raczej rola

5 Por. H.M. Levin, The Public-Private Nexus in Education, „The American Behavioral Scientist” Vol. 43, No. 1, September 1999, s. 124-137; J.E. Stiglitz, The Demand for Education in Public and Private School Systems, „Journal of Public Economics” 3, 1974, s. 349-385.

6 Por. R.G. Holcombe, A Theory of the Theory of Public Goods, „Review of Austrian Economics” Vol. 10, No. 1, 1997, s. 1-22, https://www.keionline.org/misc-docs/socialgoods/Holcombe_1997_TheoryofPublicGoods.pdf [dostęp 23.02.2018].

7 Por. E.H. Klijn, Public Private Partnership: deciphering meaning, message and phenomenon, [w:] International Handbook of PPP, red. G. Hodge, C. Greve, Edgar Elgar, Cheltenham 2010, s. 68-80.

8 D. Barak-Erez, The Privatization Continuum, [w:] Private security, public order: the outsourcing of public services and its limits, red. S. Chesterman, A. Fisher, Oxford University Press, Oxford-New York 2009, http://www.tau.ac.il/law/barakerez/artmarch2010/42.pdf [dostęp 15.02.2018].

9 Zob. np. J.E. Lane, New Public Management: An Introduction, Routledge, New York 2002; A. Zalewski, Reformy sektora publicznego $w$ duchu nowego zarzadzania publicznego, [w:] Nowe zarzadzanie publiczne w polskim samorzadzie terytorialnym, red. A. Zalewski, Oficyna Wydawnicza SGH, Warszawa 2007, s. 11-73.

10 Zob. np. K. McLaughlin, E. Ferlie, S.P. Osborne, New Public Management: Current Trends and Future Prospects, Routledge, New York 2005.

11 Por. L. Blomgren Bingham, T. Nabatchi, R. O'Leary, The New Governance: Practices and Processes for Stakeholder and Citizen Participation in the Work of Government, „Public Administration Review” Vol. 65, No. 5, September/October 2005, http://unpan1.un.org/intradoc/groups/public/documents/un-dpadm/ unpan039447.pdf [dostęp 15.02.2018]. 
koordynatora i podmiotu nadzorującego aniżeli bezpośredniego wykonawcy usług publicznych lub jedynie zamawiającego dane usługi na rynku.

Podmioty komercyjne zaczęły postrzegać świadczenie usług publicznych jako korzystne, zyskowne i bezpieczne przede wszystkim ze względu na stosunkowo niskie ryzyko niepowodzenia biznesowego oraz stabilne finansowanie ze środków publicznych. W literaturze można spotkać się z oceną, że nurt New Governance w jeszcze większym stopniu niż New Public Management poszerzył możliwości wejścia podmiotów prywatnych do sektora edukacji ${ }^{12}$. Rozwiązania te okazały się optymalne dla sektora prywatnego, gdyż dotychczasowe konkurowanie w niepewnych warunkach zmieniono $\mathrm{w} \mathrm{w}$ miarę pewną, stałą, nieprzerwaną i gwarantowaną przez państwo działalność w podstawowych usługach dla ludności ${ }^{13}$. Paradygmat rynkowej konkurencji i rywalizacji został zastąpiony przez pozytywny paradygmat współpracy i współzarządzania ${ }^{14}$.

Mechanizm partnerstwa publicznego wykazuje zalety i wady. W zwięzłej postaci opisano je w opracowaniu Banku Światowego poświęconym temu zagadnieniu ${ }^{15}$. PPP wprowadza elementy konkurencji i wyboru na rynku edukacyjnym, tworzy rozwiązania bardziej elastyczne niż stosowane przez sektor publiczny oraz wymusza ekonomiczną efektywność działania szkół. Wysuwane są także argumenty przeciw wprowadzaniu PPP do systemów oświaty: obawa o prywatyzację edukacji oraz utratę kontroli rządu nad usługami publicznymi, ryzyko wzrostu różnic społeczno-ekonomicznych, zagrożenie stabilności płacowej dla nauczycieli i innych pracowników szkół.

\section{Instrument Private Financial Initiative w Wielkiej Brytanii}

Jak wspomniano na wstępie opracowania, realizacja rządowych przedsięwzięć $\mathrm{w}$ formule PPP na szeroką skalę została zainicjowana w Wielkiej Brytanii, a inne państwa europejskie oraz USA czerpią z jej doświadczeń, chociaż z uwzględnieniem

12 S.L. Robertson, A. Verger, Governing Education Through Public Private Partnerships, Centre for Globalisation, Education and Societies, University of Bristol 2012, s. 2, https://susanleerobertson.files.wordpress. com/2012/07/2012-robertson-verger-governingeducation.pdf [dostęp 16.02.2018].

13 C. Chitty, Education Policy in Britain, Palgrave Macmillan, New York 2014, s. 104 i n.

14 R. Wettenhall, The Rhetoric and Reality of Public-Private Partnerships, „Public Organization Review: A Global Journal” No. 3, 2003, s. 77-107.

15 H.A. Patrinos, F. Barrera-Osorio, J. Guáqueta, The Role and Impact of Public-Private Partnerships in Education, The World Bank, Washington, D.C. 2009, http://www.ungei.org/files/Role_Impact_PPP_Education.pdf [dostęp 15.02.2018]. 
krajowej specyfiki i odrębności ${ }^{16}$. Stąd też warto pokrótce scharakteryzować ten model prowadzenia inwestycji publicznych. Od 1992 r. w Wielkiej Brytanii wykorzystywany jest instrument pod nazwą Private Financial Initiative (PFI) z koniecznym udziałem działania/współfinansowania prywatnego oraz z rozkładem ryzyka pomiędzy partnera publicznego i prywatnego ${ }^{17}$. Inicjatywa ta opiera się na wizji rządu jako nabywcy usług publicznych. Instrument PFI został wprowadzony przez rząd konserwatywny, ale rozkwit jego stosowania przypadł na okres rządów Partii Pracy w latach 1997-2010.

PFI ewoluowała od wersji pierwotnie ograniczonej do „twardych” inwestycji infrastrukturalnych (np. w dziedzinie transportu) w kierunku narzędzia zastępującego inwestycje ze środków budżetowych prowadzone w tradycyjnej formie (in-house) oraz obejmującego wykonywanie w sposób kompleksowy zadań publicznych w obszarach takich jak edukacja, ochrona zdrowia czy mieszkalnictwo ${ }^{18}$. W 2003 r. gabinet premiera T. Blaira rozpoczął zakrojony na 20 lat inwestycyjny program budowy i modernizacji wszystkich szkół średnich pod nazwą „Building Schools for the Future”19. W jego efekcie w ostatnich dziesięcioleciach praktycznie wszystkie nowe szkoły w Anglii budowane były w formule PPP (PFI $)^{20}$.

Bilans przedsięwzięć realizowanych w ramach PFI jest niejednoznaczny, a zasadność samej inicjatywy - kwestionowana ${ }^{21}$. Private Finance Initiative radykalnie przedefiniowała sposób świadczenia usług publicznych, nierzadko podnosząc ich koszty,

16 Zob. np. B. Augustyńska, Koncepcja partnerstwa publiczno-prywatnego na przykładzie Holandii, „Zarządzanie Publiczne”, „Zeszyty Naukowe ISP UJ” 3, 2007, s. 145-153, http://www.ejournals.eu/sj/index.php/ ZP/article/viewFile/1025/1021 [dostęp 15.02.2018].

17 Zob. np. D. Corner, The United Kingdom Private Finance Initiative: The Challenge of Allocating Risk, „OECD Journal on Budgeting” Vol. 5, No. 3, 2006, http://www.oecd.org/unitedkingdom/43479923.pdf [dostęp 15.02.2018].

18 Szerzej: B. McCabe, J. McKendrick, J. Keenan, PFI in Schools -Pass or Fail?, „Journal of Finance and Management in Public Services" Vol. 1, Summer 2001.

19 Building schools for the future. Consultation on a new approach to capital investment, Department for Education and Skills, Annesley, Nottinghamshire 2003, http://www.education.gov.uk/publications/eOrderingDownload/DfES\%200218\%20200MIG467.pdf [dostęp 13.02.2018].

20 Na poziomie lokalnym ustanawia się w tym celu spółki specjalnego przeznaczenia o kapitale mieszanym (80\% - partner prywatny, 20\% - partner publiczny,) zwane local education partnerships; J. Shaoul, A. Stafford, P. Stampleton, Accountability for public expenditure under „Building Schools for the Future”, [w:] Education, Capitalism and the Global Crisis, red. S.J. Ball, M. Maguire, I.F. Goodsons, Routledge-Taylor\&Francis, London-New York 2012, s. 51. Na brytyjskie samorządy wywierany był polityczny nacisk ze strony władz centralnych, aby inwestycje oświatowe realizować właśnie w formule PFI. Nacisk ten jest wzmacniany mechanizmem finansowania samorządu terytorialnego, który $80 \%$ swoich dochodów uzyskuje $\mathrm{z}$ dotacji i subwencji z budżetu państwa; A. Kopańska, Partnerstwo publiczno-prywatne - wzory brytyjskie. Czego możemy się z nich nauczyć, „Studia Regionalne i Lokalne” nr 3(25), 2006, s. 83-98, http://www.studreg. uw.edu.pl/pdf/2006_3_kopanska.pdf [dostęp 15.02.2018].

21 Wielkim krytykiem PFI są nauczycielskie związki zawodowe, zob. np. Contesting Neoliberal Education: Public Resistance and Collective Advance, red. D. Hill, Routledge, London 2009. 
ograniczając w tej materii uprawnienia decyzyjne władz samorządu lokalnego oraz eliminując z rynku miejscowe przedsiębiorstwa ${ }^{22}$. Na nadmierne koszty projektów realizowanych w ramach PPP i PFI w kolejnych edycjach programu ${ }^{23}$ oraz nierównomierny rozkład ryzyka zwróciło uwagę brytyjskie Narodowe Biuro Audytu (National Audit Office - NAO), wzywając rząd do opracowania innych metod i modeli finansowania przedsięwzięć z zakresu użyteczności publicznej ${ }^{24}$. Uwagi o nieefektywności dotyczyły także realizacji programu „Building Schools for the Future”25. Obecnie w Wielkiej Brytanii trwa dyskusja publiczna nad zasadnością kontynuowania inwestycji publicznych w formule $\mathrm{PFI}^{26}$. W szczególności podnosi się argument o wysokich (nadmiernych?) zyskach operatorów prywatnych, a audytorzy NAO wskazują, że całkowity koszt wieloletnich projektów realizowanych jako PFI może być nawet o 40\% wyższy niż projektów finansowanych w całości ze środków publicznych ${ }^{27}$.

\section{Partnerstwo publiczno-prywatne w realizacji inwestycji oświatowych}

Usługi użyteczności publicznej realizowane w ramach PPP zwykle zorganizowane są w taki sposób, że podmiot prywatny buduje i zapewnia (za wynagrodzeniem) dostęp do obiektów, a sektor publiczny korzysta z tych obiektów w celu świadczenia

22 Większość kontraktów na przedsięwzięcia prowadzone w ramach PFI zostało przejętych przez duże, często międzynarodowe korporacje; zob. np. M. Hellowell, D. Price, A.M. Pollock, The use of Private Finance Initiative (PFI) Public Private Partnerships (PPPs) in Northern Ireland, University of Edinburgh, Northern Ireland Public Service Alliance 2008, http://www.sps.ed.ac.uk/_data/assets/pdf_file/0008/64358/AAA_PFI-PPP_Booklet_12-08.pdf [dostęp 15.02.2018].

23 Po objęciu władzy przez rząd konserwatywny w 2010 r. projekty programu „Building Schools for the Future”, które nie weszły w finalną fazę realizacji, zostały zakończone, a sam program w 2012 r. zastąpiony programem „Priority Schools Building Programme” (PSBP1), a w 2015 r. - programem „Priority Schools Building Programme 2” (PSBP2); zbiory dokumentów programowych są dostępne na stronach: https:// www.gov.uk/government/collections/priority-school-building-programme-psbp oraz https://www.gov.uk/ government/publications/priority-school-building-programme-2-psbp2 [dostęp 15.02.2018].

24 Lessons from PFI and other projects, National Audit Office, London, 28.04.2011, https://www.nao.org. uk/wp-content/uploads/2011/04/1012920.pdf [dostęp 15.02.2018].

25 The Building Schools for the Future Programme. Renewing the secondary school estate, Report by The Comptroller and Auditor General, HC 135 Session 2008-2009, National Audit Office, London, 12.02.2009, https://www.nao.org.uk/wp-content/uploads/2009/02/0809135.pdf [dostęp 15.02.2018].

26 W 2017 r. zapowiedziano przegląd kontraktów zawartych w ramach PFI (i ewentualną kontynuację niektórych już rozpoczętych przedsięwzięć w formule in-house) oraz rezygnację z zawierania nowych umów PFI; zob. J. Pickard, G. Plimmer, Labour party threatens to nationalise PFI contracts, „Financial Times” 25.09.2017, https://www.ft.com/content/0161cc52-a1e9-11e7-9e4f-7f5e6a7c98a2 [dostęp 15.02.2018].

27 PFI and PF2, Report by the Comptroller and Auditor General, National Audit Office, 18.01.2018, s. 15, https://www.nao.org.uk/wp-content/uploads/2018/01/PFI-and-PF2.pdf [dostęp 27.02.2018]. 
usług $^{28}$. W obszarze edukacji typowe projekty z zakresu PPP obejmują budowę bądź rozbudowę budynków szkół i przedszkoli, a następnie eksploatację i utrzymywanie tych budynków przez wyznaczony okres (20-30 lat). PPP nie są odpowiednim rozwiązaniem w każdym przypadku, lecz mogą zapewnić pewne korzyści, jeżeli zostaną odpowiednio wykorzystane we właściwych projektach.

Liczba inwestycji publicznych realizowanych $\mathrm{w}$ formule PPP systematycznie rośnie w całej Europie - według danych i metodologii Europejskiego Banku Inwestycyjnego (EIB) łącznie od 1990 r. realizowane były (są) 1803 przedsięwzięcia tego typu o wartości 367,9 mld euro. Proces ten zintensyfikował się po 2000 r., wraz z upowszechnianiem się w państwach europejskich modelu zarządzania New Governance.

Tabela 1. Skumulowana liczba i wartość projektów PPP ogółem i w wybranych sektorach w latach 1990-2017

\begin{tabular}{|c|c|c|c|c|c|c|c|c|}
\hline & \multicolumn{2}{|c|}{ Wszystkie sektory } & \multicolumn{2}{|c|}{ Transport } & \multicolumn{2}{|c|}{ Ochrona zdrowia } & \multicolumn{2}{|c|}{ Edukacja } \\
\hline & 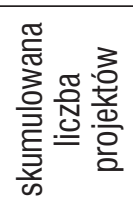 & 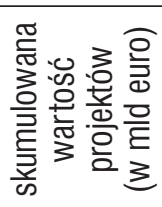 & 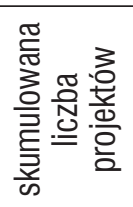 & 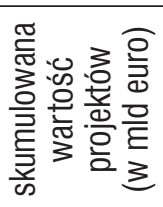 & 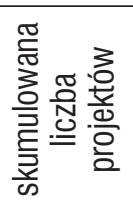 & 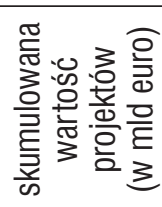 & 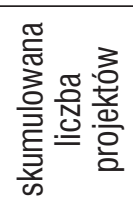 & 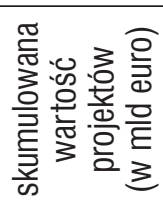 \\
\hline 1990 & 1 & 1,4 & 1 & 1,4 & 0 & 0,0 & 0 & 0,0 \\
\hline 1995 & 15 & 6,6 & 8 & 5,1 & 0 & 0,0 & 1 & 0,02 \\
\hline 2000 & 293 & 64,1 & 74 & 43,5 & 57 & 5,1 & 36 & 2,1 \\
\hline 2005 & 756 & 149,2 & 154 & 90,3 & 184 & 17,2 & 154 & 10,8 \\
\hline 2010 & 1343 & 259,8 & 284 & 143,4 & 315 & 35,1 & 309 & 26,7 \\
\hline 2015 & 1696 & 343,9 & 362 & 193,5 & 365 & 43,9 & 398 & 32,5 \\
\hline 2016 & 1765 & 355,9 & 373 & 197,3 & 379 & 46,1 & 425 & 34,1 \\
\hline 2017 & 1803 & 367,9 & 383 & 204,8 & 388 & 49,8 & 435 & 35,1 \\
\hline
\end{tabular}

Źródło: Opracowanie własne na podstawie danych European PPP Expertise Centre ${ }^{29}$.

Największą dynamiką, pod względem ilości i wartości pieniężnej, charakteryzowały się inwestycje właśnie w sektorze edukacji. W porównaniu ze stanem z roku 2000 liczba projektów z tego obszaru w 2017 r. wzrosła ponad dziesięciokrotnie, a ich wolumen finansowy - ponad piętnastokrotnie. W 2017 r. projekty oświatowe stanowily

28 Formy współpracy uzależnione są od specyfiki danego zadania i danego przedsięwzięcia, ale najczęściej wyróżnia się: 1) BTO (Build-Operate-Transfer) - Buduj-Eksploatuj-Przekaż; 2) DBFO (Design-BuildFinance-Operate) - Projektuj-Buduj-Finansuj-Eksploatuj; 3) BOO (Build-Own-Operate) - Buduj-Posiadaj-Eksploatuj; 4) BTL (Build-Transfer-Leaser) - Buduj-Przekaż-Dzierżaw; zob. E.R. Yescombe, Public-Private Partnerships: Principles of Policy and Finance, Elsevier Finance, Butterworth-Heinemann, Oxford 2007, s. 12; Partnerstwo publiczno-prywatne, red. G. Gołębiowski, K. Marchewka-Bartkowiak, „Studia BAS" nr 3(39), 2014.

29 European PPP Expertise Centre, EPEC Data Portal, http://data.eib.org/epec [dostęp 24.06.2018]. 
już niemal jedną czwartą wszystkich projektów PPP (rozpoczynanych i kontynuowanych), a ich wartość finansowa sięgnęła prawie 10\% łącznej wartości wszystkich inwestycji PPP. Wśród nowych projektów (umów podpisanych w 2017 r.) najwięcej dotyczyło sektora edukacji i transportu, najwyższą wartość, ze względu na skalę projektów, nieodmienne wykazują przedsięwzięcia transportowe. Baza danych EIB nie identyfikuje jednak wszystkich projektów PPP, w tym z zakresu edukacji. Na przykład w Belgii w roku 2010 zostały zainicjowane projekty PPP, w ramach których przewidziano budowę, remont lub modernizację łącznie 208 szkół; podobnie w Walii (Wielka Brytania) wdrażany jest program „'21st Century Schools Capital Programme”, mający na celu modernizację i podniesienie standardu wszystkich obiektów szkolnych ${ }^{30}$.

Powyższe dane ilustrują przesunięcia kierunków realizacji inwestycji $\mathrm{w}$ formule PPP, analogicznie jak to miało miejsce w przypadku PFI, tj. z infrastruktury technicznej w infrastrukturę społeczną. Oświata jest jedną z podstawowych usług zapewnianą przez sektor publiczny, jednocześnie chronicznie niedoinwestowaną, stąd pokusa władz publicznych do sięgnięcia po środki i zasoby prywatne. Podmioty komercyjne odpowiadają na to zapotrzebowanie, dostrzegając długofalowe korzyści i znikome ryzyko biznesowe ${ }^{31}$.

\section{Przekazanie prowadzenia szkoły samorządowej podmiotowi prywatnemu jako szczególna postać PPP w polskim systemie oświaty}

W Polsce zasadnicza część zadań z zakresu oświaty publicznej jest przypisana jednostkom samorządu terytorialnego, które wykonują zadania oświatowe jako obowiązkowe zadania własne. Pogarszająca się kondycja finansowa samorządów oraz legislacyjne ograniczenia możliwości zwiększania zadłużenia w JST determinują poszukiwanie nowych sposobów realizacji tych obowiązków, w tym w formie zlecania i outsourcingu zadań publicznych ${ }^{32}$.

30 Financing Schools in Europe: Mechanisms, Methods and Criteria in Public Funding, Eurydice Report, European Commission/EACEA/Eurydice, Publications Office of the European Union, Luxembourg 2014, s. 33.

31 Zdarza się, że prywatni operatorzy mają w umowach PPP zagwarantowane finansowanie publiczne nawet w przypadku konieczności likwidacji szkoły ze względu na brak chętnych uczniów. Zob. np. B. Aritua, N.J. Smith, R. Athiyo, Private finance for the delivery of school projects in England, „Management, Procurement and Law" 161 (MP4), 2008, s. 141-146, http://eprints.whiterose.ac.uk/5369/2/aritua_et_al.pdf [dostęp 15.02.2018].

32 B. Włodarczyk, Ekonomiczne i prawne bariery rozwoju partnerstwa publiczno-prywatnego w Polsce, „Optimum. Studia Ekonomiczne” nr 1(61), 2013, s. 106-123. 
Zagadnienie kontraktowania zadań oświatowych pojawiło się w Polsce pod koniec lat 90 . wraz z rozpoczynającą się reformą edukacji, która gruntownie przebudowała system szkolny ${ }^{33}$. Sieć szkolna została poddana konsolidacji w reakcji na postępujący niż demograficzny oraz niedostateczny stan techniczny części szkolnych budynków i infrastruktury. Poszukiwano nowych form zarządzania oświatą w napiętych warunkach budżetowych, tak aby zabezpieczyć funkcjonowanie szkół o wysokich kosztach utrzymania, nie wywołując konfliktów społecznych wzmożonym procesem ich likwidacji. W pierwszych latach XXI w. realizowany był program „Mała Szkoła”, polegający na tworzeniu warunków organizacyjnych i finansowych do prowadzenia małych wiejskich szkół przez stowarzyszenia skupiające rodziców i członków społeczności lokalnych ${ }^{34}$. Przejęcie przez stowarzyszenie prowadzenia dotychczasowej szkoły gminnej wymagało jednak wówczas postawienia tej szkoły w stan likwidacji, co wywoływało niepokoje rodziców. Instytucja małej szkoły nie doczekała się osadzenia w przepisach oświatowych.

Mając na uwadze przedstawione ograniczenia, projektując nowe rozwiązania w $2009 \mathrm{r}^{35}$, zabezpieczono gwarancje funkcjonowania szkoły zamierzonej do przekazania podmiotowi prywatnemu. Według obowiązującego stanu prawnego jednostka samorządu terytorialnego prowadząca szkołę liczącą nie więcej niż 70 uczniów, na podstawie uchwały organu stanowiącego tej jednostki oraz po uzyskaniu pozytywnej opinii kuratora oświaty, może przekazać z dniem 1 września danego roku, w drodze umowy, osobie prawnej niebędącej jednostką samorządu terytorialnego, lub osobie fizycznej, prowadzenie takiej szkoły, o ile szkoła ta nie jest jedyną szkołą danego typu prowadzoną przez tę jednostkę samorządu terytorialnego ${ }^{36}$. Podmiot,

33 Zob. np. Decentralizacja oświaty, red. M. Herbst, „Biblioteczka Oświaty Samorządowej” t. 7, Ośrodek Rozwoju Edukacji, Warszawa 2012.

34 Zob. A. Kozińska-Bałdyga, Małe Szkoły - jak to było, „Mała szkoła - wielka szansa, VII Forum Inicjatyw Oświatowych", Sejm, 2-3.12.2000, http://fio.org.pl/images/dodatki/fora/200012_7forum_kozinska_ ms.pdf [dostęp 15.02.2018].

35 Skorzystano wówczas z wyników badania CBOS, zgodnie z którymi $68 \%$ ankietowanych (75\% mających dzieci w wieku powyżej 6 lat) opowiadało się za przekazaniem prowadzenia małej szkoły (z pominięciem procesu jej likwidacji) innemu niż JST organowi, w sytuacji gdy byt tej szkoły jest zagrożony z powodu zbyt wysokich kosztów jej działania. Wśród warunków towarzyszących przekazaniu szkoły innemu podmiotowi respondenci wymieniali zagwarantowanie uczniom kontynuacji bezpłatnego kształcenia (92\%), zagwarantowanie uczniom co najmniej takiej samej lub lepszej oferty kształcenia (93\%), użyczenie budynku szkoły i jej wyposażenia nowemu organowi na czas prowadzenia szkoły (85\%), zagwarantowanie ciągłości finansowania szkoły ze środków publicznych (83\%) oraz zagwarantowanie nauczycielom możliwości kontynuacji zatrudnienia w tej samej szkole (84\%). Zob. Problem likwidacji szkót. Komunikat z badań, Komunikat Centrum Badania Opinii Społecznej, Warszawa, styczeń 2009.

36 Podstawa prawna do przekazania prowadzenia szkoły samorządowej podmiotowi zewnętrznemu została ustanowiona mocą art. 5 ust. $5 \mathrm{~g}$ i n. Ustawy z dnia 19 marca 2009 r. o zmianie ustawy o systemie oświaty oraz o zmianie niektórych innych ustaw, DzU 2009, nr 56, poz. 458 z późn. zm. Obecnie obowiązuje w tym zakresie art. 9 Ustawy z dnia 14 grudnia 2016 r. - Prawo oświatowe, DzU 2018, poz. 996. 
który przejął prowadzenie szkoły, nie może jej zlikwidować, a JST - np. w przypadku wycofania się operatora - ma obowiązek zwrotnego przejęcia szkoły. Nie można przekazać ostatniej lub jedynej szkoły samorządowej. Przedmiotem umowy nie może być także przyznanie osobie fizycznej lub osobie prawnej prawa do założenia w tym trybie nowej szkoły publicznej.

Przepisy wykluczają również powierzenie bądź przekazanie przez jednostkę samorządu terytorialnego wykonywania zadań oświatowych spółce komunalnej. W szczególności JST nie może przekazać takiej spółce prowadzenia szkoły publicznej, ani udzielić jej zezwolenia na założenie szkoły publicznej. Możliwe jest jednak założenie przez spółkę komunalną szkoły lub przedszkola niepublicznego, prowadzenie bowiem takich szkół i przedszkoli nie stanowi oświatowego zadania własnego samorządu terytorialnego ${ }^{37}$.

Małym szkołom przekazanym do prowadzenia na podstawie umowy gwarantuje się stabilne finansowanie z budżetu jednostki samorządu terytorialnego, która szkołę przekazała (dotacja od dnia przekazania, również w okresie ferii letnich). Wysokość dotacji jest równa iloczynowi kwoty przekazywanej przez państwo na danego ucznia w części oświatowej subwencji ogólnej dla JST oraz odpowiedniego wskaźnika zwiększającego ${ }^{38}$. Standardem finansowym jest więc odpowiednio skalkulowana kwota części oświatowej subwencji ogólnej (w przeliczeniu na jednego ucznia o danej charakterystyce) przekazywana z budżetu państwa na pokrycie wydatków bieżących ponoszonych na kształcenie tego ucznia. Od 2015 r. mechanizm finansowania uwzględnia dodatkowe środki dla szkół podstawowych (niezależnie od ich organu prowadzącego), w których liczba uczniów nie przekracza 70. Od dnia 1 stycznia 2018 r. za małą szkołę należy uważać szkołę podstawową dla dzieci i młodzieży, w której średnia liczebność klasy jest niższa lub równa 12 uczniom ${ }^{39}$. Wartość dodatkowych środków na jednego ucznia małej szkoły wynosi w roku 2018 około $1169 \mathrm{zł}$ (w 2017 r. - $1052 \mathrm{zl}$ ).

Przekazanie prowadzenia szkoły publicznej podmiotowi niepublicznemu skutkuje odmiennymi zasadami zatrudniania i wynagradzania nauczycieli tej szkoły (przejście

37 W gminie Środa Wielkopolska spółka samorządowa założona w 2011 r. prowadzi w roku szkolnym 2017/2018 osiem niepublicznych przedszkoli (http://sroda21.eu/wp-content/uploads/2018/02/REGULAMIN_REKRUTACJI-2018-2019.docx). Ponadto spółka ta jest założycielem i udziałowcem innej spółki, która prowadzi trzy niepubliczne szkoły podstawowe, niepobierające opłat za kształcenie. Do końca roku szkolnego 2012/2013 szkoły te były prowadzone jako szkoły publiczne (http://gazetasredzka.pl/aktualnosci/ sroda-xxi-edu---spolka-do-prowadzenia-szkol-jaroslawiec-plawce-brodowo,a21437c1 [dostęp 2.03.2018]).

38 Art. 25 ust. 1 i 2 Ustawy z dnia 27 października 2017 r. o finansowaniu zadań oświatowych, DzU poz. 2203.

39 Rozporządzenie Ministra Edukacji Narodowej z dnia 15 grudnia 2017 r. w sprawie sposobu podziału części oświatowej subwencji ogólnej dla jednostek samorządu terytorialnego w roku 2018, DzU poz. 2395. 
z regulacji Karty Nauczyciela na mniej korzystne regulacje Kodeksu pracy). Przekazana szkoła użytkuje mienie, które znajdowało się w trwałym zarządzie tej szkoły przed jej przekazaniem, na zasadach określonych w umowie. Własnością JST pozostaje substrat majątkowy (obiekty szkolne, wyposażenie), ale nie szkoła w sensie organizacyjno-prawnym. Szkoła przekazana do prowadzenia w omawianym trybie zachowuje swój publiczny charakter i status, związany z powszechną dostępnością oraz bezpłatnością w zakresie obowiązkowych zajęć edukacyjnych.

Dane dotyczące liczby szkół publicznych przekazanych na podstawie umowy nie są spójne i kompletne. Według szacunków MEN w okresie od kwietnia 2009 r. do września 2015 r. jednostki samorządu terytorialnego przekazały 234 szkoły podstawowe, 9 gimnazjów, 2 szkoły ponadgimnazjalne i 25 placówek wychowania przedszkolnego. Natomiast według danych Systemu Informacji Oświatowej między rokiem szkolnym 2016/2017 a rokiem 2017/2018 łącznie przekazano do prowadzenia podmiotom prywatnym 177 jednostek oświatowych.

Rysunek 1. Udział procentowy szkół i placówek przekazanych na podstawie umowy według typów

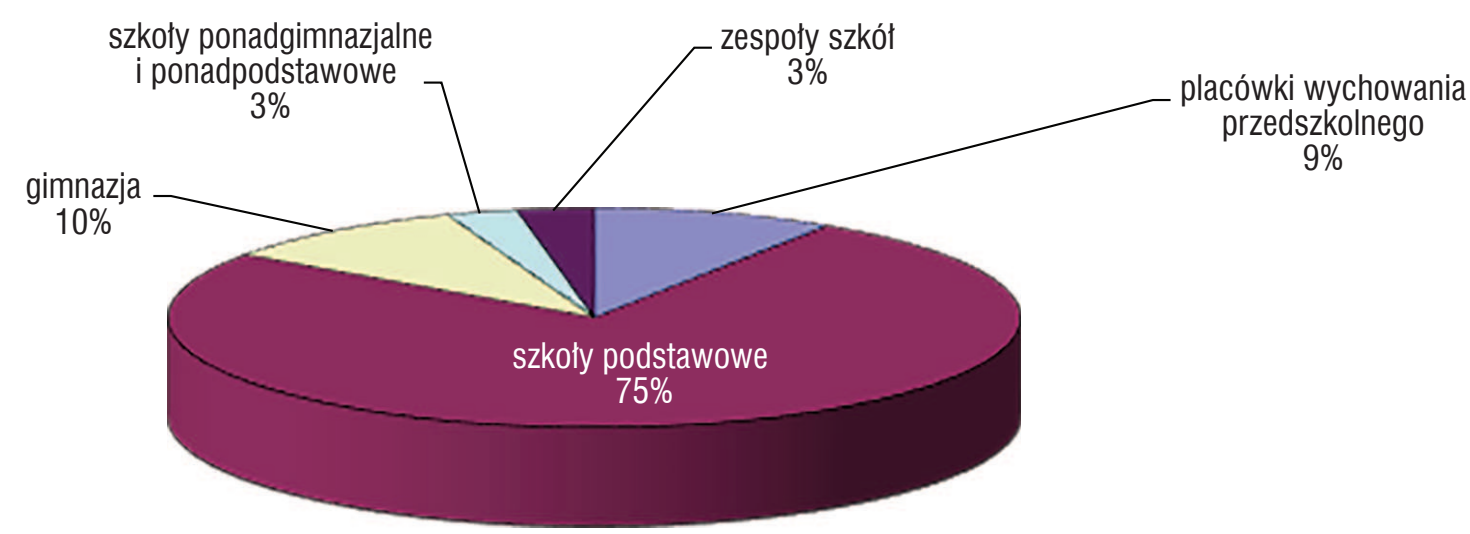

Źródło: System Informacji Oświatowej.

Wśród przekazanych jednostek dominują szkoły podstawowe. Instytucja przekazania szkoły samorządowej podmiotowi niepublicznemu była tworzona z myślą o potrzebach gmin zobowiązanych do zapewnienia realizacji obowiązku szkolnego możliwie jak najbliżej miejsca zamieszkania ucznia i niechętnych poddawania szkół podstawowych procesowi likwidacji. O wiele rzadziej przekazywane są inne typy jednostek prowadzonych przez gminy, tj. przedszkola i gimnazja. W przypadku gimnazjów sieć tych szkół jest bardziej rozproszona, nierzadko w gminie funkcjonuje tylko jedno zbiorcze gimnazjum, co wyklucza możliwość powierzenia jego prowadzenia przez podmiot zewnętrzny. $Z$ kolei edukacja przedszkolna nie wpisuje się w kategorię obowiązku szkolnego (dzieciom przysługuje prawo do wychowania 
przedszkolnego), a sama sieć przedszkoli publicznych jest już istotnie uzupełniania przez przedszkola niepubliczne (stanowiące już ponad 40\% wszystkich placówek). Wdrażana od dnia 1 września 2017 r. reforma ustroju szkolnego przewidująca wygaszenie gimnazjum, przywrócenie 8-letniej szkoły podstawowej i zagęszczenie sieci szkolnej może wpłynąć na zwiększenie liczby szkół podstawowych przekazywanych podmiotom prywatnym.

\section{Idea szkół wspólnotowych - community schools}

Opisana powyżej instytucja przekazania szkoły publicznej do prowadzenia podmiotowi niepublicznemu nawiązuje do idei tzw. community schools - szkół wspólnotowych, tj. szkól, w których zarządzaniu i finansowaniu uczestniczą rodzice, organizacje społeczne, a nawet miejscowi przedsiębiorcy. Wspólnotowość szkoły może przybierać m.in. wymiar geograficzny, rodzinny, etniczny czy religijny ${ }^{40}$. Zakłada ona, że uczestników wspólnego działania łączy jakiś wspólny cel i wspólny interes, co nie oznacza automatycznie zgodności co do sposobów i środków osiągnięcia tego celu. W literaturze przedmiotu wyodrębnia się zasadnicze właściwości charakteryzujące wspólnotę, takie jak sieć wspólnych potrzeb i interesów przekraczających interesy pojedynczych gospodarstw domowych, symboliczna lub rzeczywista baza (np. miejscowość, obwód szkolny) oraz jakieś cechy odróżniające tę wspólnotę od innych podobnych grup ${ }^{41}$. Idea szkół wspólnotowych rozwinęła się w szczególności w państwach anglosaskich, zwłaszcza w USA i w Australii, także w odniesieniu do tzw. rdzennych grup etnicznych ${ }^{42}$. Formułę tę zalecały także międzynarodowe organizacje i instytucje pomocowe przy reformowaniu systemów edukacyjnych państw ubogich i rozwijających się ${ }^{43}$. Prowadzenie szkól jako wspólnotowych pozwalało

40 Zob. M. Bray, Community Partnerships in Education: Dimensions. Variations and Implications, Thematic Studies, Education for all 2000 Assessment, World Education Forum Dakar, Senegal, 26-28.04.2000, UNESCO, Paris 2001, s. 5, http://unesdoc.unesco.org/images/0012/001234/123483e.pdf [dostęp 23.02.2018].

41 J. Wolf, E. Kane, B. Strickland, Planning for Community Participation in Education, Prepared for the Office of Sustainable Development Bureau for Africa, U.S. Agency for International Development, Washington, D.C., February 1997, s. 9, http://pdf.usaid.gov/pdf_docs/PNACA364.pdf [dostęp 23.02.2018].

42 School-Community Partnerships in Australian Schools, Australian Council for Educational Research, November 2010, https://research.acer.edu.au/cgi/viewcontent.cgi?article=1006\&context=policy_analysis_ misc; M.J. Blank, A. Melaville, B.P. Shah, Making the Difference: Research and Practice in Community Schools, Coalition for Community Schools, Institute for Educational Leadership, Washington, D.C. 2003, https:// files.eric.ed.gov/fulltext/ED499103.pdf [dostęp 23.02.2018].

43 B. Bruns, D. Filmer, H.A. Patrinos, Making Schools Work. New Evidence on Accountability Reforms, The World Bank, Washington, D.C. 2011, http://siteresources.worldbank.org/EDUCATION/Resources/278200-1298568319076/makingschoolswork.pdf [dostęp 23.02.2018]. 
na utrzymanie szkół na obszarach wiejskich i peryferyjnych, o niskiej gęstości zaludnienia i słabo rozwiniętej infrastrukturze społecznej ${ }^{44}$.

W Polsce idea szkół wspólnotowych towarzyszyła procesowi decentralizacji zarządzania oświatą. W tworzenie szkół wspólnotowych włączały się organizacje pozarządowe, których celem było ratowanie wiejskich szkół przed likwidacją ${ }^{45}$. Szkoły te, oprócz realizowania funkcji edukacyjnej, spełniają ważną rolę kulturotwórczą, ekonomiczną oraz integracyjną ${ }^{46}$. Nierzadko zamknięcie szkoły w danej miejscowości doprowadzało do jej wyludnienia i społeczno-gospodarczej degradacji ${ }^{47}$. Ruch szkół wspólnotowych, choć wprost tak nienazwanych, w pierwszej fazie swego kształtowania skupiał się przede wszystkim na wypracowywaniu alternatywnych metod prowadzenia szkół na obszarach wiejskich, a więc zrodził się w odpowiedzi na potrzeby praktyki i zjawiska kryzysowe w polskiej oświacie ${ }^{48}$.

W roku 2014 został w przestrzeni publicznej zaprezentowany przez Stowarzyszenie Forum Od-Nowa pomysł tworzenia w Polsce szkół wspólnotowych jako rozwiązania systemowego, mającego mieć zastosowanie do całego systemu oświaty. Autorzy koncepcji zaproponowali wprowadzenie możliwości powierzenia stowarzyszeniom lokalnym prowadzenia wszystkich szkół samorządowych (bez ograniczeń związanych np. z wielkością czy typem szkoły), określenie nowego modelu finansowania jednostek oświatowych z wykorzystaniem „metod partycypacyjnych” (może to oznaczać częściową odpłatność za wybrane usługi edukacyjne), zatrudnianie nauczycieli w oparciu o Kodeks pracy oraz uspołecznienie komunalnego mienia szkolnego (stowarzyszenia rodziców miałyby stać się wraz z jednostką samorządu terytorialnego współwłaścicielem budynku szkoły wybudowanego przez mieszkańców wsi) ${ }^{49}$.

44 Por. D. Terry Williams, The Rural Solution. How Community Schools Can Reinvigorate Rural Education, Rural School and Community Trust, September 2010, https://cdn.americanprogress.org/wp-content/ uploads/issues/2010/09/pdf/ruralschools.pdf [dostęp 23.02.2018].

45 Zob. A. Rutkowska, Mały cud oświatowy - rola stowarzyszeń rozwoju wsi w przejmowaniu i prowadzeniu małych szkół (przykład województwa kujawsko-pomorskiego), „Chowanna” 1, 2015, s. 77-90.

46 Zob. np. A. Bajerski, A. Błaszczyk, Likwidacja szkół podstawowych na wsi: perspektywa władz lokalnych, nauczycieli, rodziców, uczniów i pozostałych mieszkańców, „Przegląd Badań Edukacyjnych - Educational Studies Review" nr 21(2), 2015, s. 81-105.

47 A.J. DeYoung, C.B. Howley, The Political Economy of Rural School Consolidation, „Peabody Journal of Education” Vol. 67, No. 4, „A Look at Rural Education in the United States” Summer 1990, s. 63-89.

48 Por. A. Dziemianowicz-Bąk, J. Dzierzgowski, Likwidacja szkót podstawowych oraz przekazywanie stowarzyszeniom. Kontekst, proces i skutki przemian edukacyjnych $w$ społecznościach lokalnych na podstawie analizy studiów przypadku, Instytut Badan Edukacyjnych, Warszawa 2014.

49 Zob. Na ratunek likwidowanym szkołom, Forum_Od Nowa, 16.09.2014, http://forumod-nowa.liberte. pl/na-ratunek-likwidowanym-szkolom/. Koncepcja szkół wspólnotowych została oparta na wynikach projektu innowacyjnego „Od partnerstwa do kooperacji” realizowanego w latach 2012-2015 w ramach Programu Operacyjnego Kapitał Ludzki 2007-2013. W projekcie opracowano model zlecania realizacji zadań przez samorządy organizacjom pozarządowym - Model Kontraktowania Usług Społecznych (http://www.zlecaniezadan.pl). Model ten obejmuje m.in. zlecanie prowadzenia trwałej instytucji o charakterze publicznym, świadczącej usługi na rzecz społeczności, np. szkoły lub przedszkola. Inny projekt, realizowany przez Fun- 
W środowiskach wiejskich szkoła utożsamiana jest z budynkiem szkolnym stanowiącym na ogół zasób własności gminnej. Brak dostępu do bazy lokalowej stanowi istotną barierę wejścia na rynek oświatowy w danej JST. Nawet gdy dany podmiot (niedysponujący własną nieruchomością) jest zainteresowany założeniem i prowadzeniem szkoły na terenie danej gminy, bez przychylności jej władz umożliwiających korzystanie z gminnego mienia szkolnego jest to praktycznie niewykonalne. Z powyższego względu dla środowisk związanych z promowaniem idei szkół wspólnotowych najistotniejszy wydaje się postulat wprowadzenia do ustawodawstwa instytucji tzw. mienia oświatowego, tak aby podmiotem tego mienia mogły stać się sołectwa lub organizacje pozarządowe prowadzące szkoły ${ }^{50}$. Propozycję tę należy ocenić jako trudną do realizacji - prowadziła ona w istocie do wywłaszczenia samorządu terytorialnego z jego majątku.

Osadzenie w porządku prawnym szkół wspólnotowych formalnie administrowanych przez stowarzyszenia niezależne od jednostki samorządu terytorialnego, lecz faktycznie tworzonych w oparciu o powiązania personalne i majątkowe, mogłoby stanowić dalszy krok w kierunku urzeczywistnienia idei PPP w oświacie, tj. współprowadzenia przez jednostkę samorządu terytorialnego szkoły publicznej wraz z podmiotem prywatnym. W obecnym stanie prawnym instytucjonalna współpraca gmin i organizacji prywatnych działających jako jeden organ prowadzący szkołę nie jest dopuszczalna. Niemniej należy w tym miejscu wspomnieć o przewidzianym przez porządek prawny Polski i Unii Europejskiej instrumencie partycypacji społecznej w zarządzaniu bieżącymi sprawami lokalnymi i rozwojem lokalnym w postaci lokalnych grup działania (LGD) ${ }^{51}$. LGD uznawane są za przykład zorganizowanego lokalnego partnerstwa trójsektorowego (zrzeszającego podmioty publicznoprawne, podmioty gospodarcze oraz organizacje pozarządowe $)^{52}$. LGD funkcjonują jako dobrowolne stowarzyszenia posiadające osobowość prawną, a ich członkami zwyczajnymi mogą być osoby fizyczne i osoby prawne, w tym gminy i powiaty. Po odpowiednim dostosowaniu prawnym lokalne grupy działania jako stowarzyszenia mogłyby się ubiegać

dację Tarcza, również miał na celu wsparcie JST w procesie kontraktowania zadań oświatowych. Zob. Opracowanie i upowszechnienie innowacyjnego modelu kontraktowania przez gminy usług społecznych $w$ zakresie edukacji podstawowej, „Zeszyty Senackie” 17, 2013, http://www.senat.gov.pl/download/gfx/senat/pl/ senatzespolyinformacje/zeszyt/z_17.pdf oraz http://fundacjatarcza.pl/projekty/w-obronie-szkoly [dostęp 25.02.2018].

50 Zob. Sprawa szkoły w Lipinach, gm. Mrozy - pole doświadczalne samorząności, 22.06.2017, http:// wiadomosci.ngo.pl/wiadomosc/2078908.html [dostęp 25.02.2018].

51 Ustawa z dnia 20 lutego 2015 r. o rozwoju lokalnym z udziałem lokalnej społeczności, DzU poz. 37 ze zm.

52 M. Furmankiewicz, Wspólpraca międzysektorowa w ramach „partnerstw terytorialnych" na obszarach wiejskich w Polsce, „Studia Regionalne i Lokalne” nr 2(24), 2006, s. 117-136. 
o możliwość realizacji wybranych zadań oświatowych na swoim obszarze, a tym samym idea szkół wspólnotowych zostałaby częściowo zrealizowana ${ }^{53}$.

\section{Realizacja inwestycji oświatowych w formule PPP w Polsce}

W polskiej praktyce administracyjnej formuła partnerstwa publiczno-prywatnego nie była dotychczas szeroko wykorzystywana przez jednostki samorządu terytorialnego przy realizacji inwestycji z zakresu oświaty. W opracowaniach o charakterze doradczym można spotkać się ze stanowiskiem, że „PPP nie jest metodą realizacji zadań publicznych odpowiednią do zastosowania w sektorach typu: kultura, edukacja i oświata ze względu na kosztochłonny charakter usług i małą rentowność" ${ }^{4}$. Ponadto z prowadzonych badań wynika, że projekty realizowane w ramach partnerstwa publiczno-prywatnego w obszarze edukacji cechują się niską skutecznością, gdyż postępowania są stosunkowo często unieważniane ${ }^{55}$. Mimo to aktywizują się podmioty prywatne (krajowe i zagraniczne) poszukujące możliwości wejścia na rynek usług oświatowych i opiekuńczych, postrzegające ten rynek jako bardzo perspektywiczny oraz opłacalny finansowo ze względu na publiczne dofinansowanie tego rodzaju działalności56.

W ramach krajowej polityki wspierania rozwoju PPP Ministerstwo Gospodarki stworzyło bazę projektów partnerstwa publiczno-prywatnego ${ }^{57}$, w której zidentyfikować można projekty z już zawartymi umowami oraz zamierzenia inwestycyjne. W sektorze edukacji w formule PPP prowadzi się przede wszystkim remonty i termomodernizację obiektów szkolnych. Inne przedsięwzięcia obejmują np. organizację dowożenia uczniów do szkół. Na 117 projektów już z zawartymi umowami (według stanu na dzień 31 grudnia $2017 \mathrm{r}^{58}$ ) 17 projektów to przedsięwzięcia

53 Por. M. Turek, Rola lokalnych grup działania w zarządzaniu rozwojem lokalnym na przykładzie małopolskich LGD w perspektywie finansowej 2007-2013, „Zarządzanie Publiczne” nr 4(24), 2013.

54 M. Wawrzyniak, Partnerstwo publiczno-prywatne jako metoda realizacji przedszkoli i żłobków przez gminy, „Biuletyn partnerstwa publiczno-prywatnego. Dobre praktyki”, PARP, Warszawa 2015, s. 70, http:// ippp.pl/wp-content/uploads/2016/03/Biuletyn-PPP-nr-13-Instytut-PPP.pdf [dostęp 28.02.2018].

55 Por. A. Chleboś, Analiza skuteczności postępowań ogłoszonych w ramach partnerstwa publiczno-prywatnego w wybranych sektorach, „Zeszyty Naukowe Politechniki Poznańskiej” nr 64, „Organizacja i Zarządzanie” 2015, s. 15-30, http://www.zeszyty.fem.put.poznan.pl/numery/ZN_OiZ_PP_64_02.pdf [dostęp 28.02.2018].

56 Hiszpanie będa niańczyć w PPP, „Puls Biznesu” 9.10.2012, https://www.pb.pl/hiszpanie-beda-nianczyc-w-ppp-690832; T. Wojtczak, PPP szansq na nowe żłobki i przedszkola, „Bankier” 21.06.2011, https:// www.bankier.pl/wiadomosc/PPP-szansa-na-nowe-zlobki-i-przedszkola-2361693.html [dostęp 15.02.2018].

57 http://www.ppp.gov.pl/baza/Strony/baza_projektow_ppp.aspx [dostęp 24.06.2018].

58 https://www.ppp.gov.pl/Aktualnosci/Documents/2018_03_20_baza_danych_umowy_PPP_.xlsx [dostęp 24.06.2018]. 
oświatowe polegające na kompleksowej modernizacji budynków szkolnych. Jedną z pierwszych tego rodzaju inwestycji o znacznej skali był projekt gminy Radzionków (kompleksowa termomodernizacja budynków szkolnych) rozpoczęty w $2010 \mathrm{r}$. i opiewający na kwotę prawie $9 \mathrm{mln} \mathrm{z}^{59}$. Przykład gminy Radzionków posłużył innym jednostkom samorządu terytorialnego. Na uwagę zasługują duże projekty miasta Zgierz o wartości ponad $56 \mathrm{mln}$ zł (okres realizacji 2017-2033) oraz miasta Bytomia o wartości $46 \mathrm{mln}$ zł (okres realizacji 2014-2029). Z kolei baza zamierzeń inwestycyjnych ${ }^{60}$ zawiera 7 projektów z sektora edukacji, m.in. planowane przedsięwzięcia m.st. Warszawy (budowa wysokoenergooszczędnych przedszkoli publicznych, wartość - $60 \mathrm{mln}$ zł), miasta Piastowa (rozbudowa liceum ogólnokształcącego i budowa hali sportowej, wartość - $21 \mathrm{mln}$ zł) czy miasta Lublina (termomodernizacja placówek oświatowych, wartość - $20 \mathrm{mln}$ zł). Ponadto zarówno w bazie już zawartych umów, jak i zamierzeń inwestycyjnych ujętych jest szereg projektów remontów i modernizacji obiektów użyteczności publicznej, przy czym ogólny opis tych projektów nie pozwala na definitywne stwierdzenie, czy dotyczą one również budynków szkolnych. Rzeczywista liczba planowanych i realizowanych projektów oświatowych może być zatem wyższa.

W dniu 26 lipca 2017 r. Rada Ministrów przyjęła „Politykę Rządu w zakresie rozwoju Partnerstwa Publiczno-Prywatnego" ${ }^{61}$. W dokumencie tym nie przesądza się wprost o możliwości wykonywania przez jednostki samorządu terytorialnego zadań publicznych z zakresu oświaty we współpracy z sektorem prywatnym, niemniej wskazano w nim, że „niezbędne jest większe zaangażowanie środków prywatnych do realizacji inwestycji i świadczenia usług publicznych”. Istotne jest, że rząd dostrzega nie tylko potrzebę zwiększenia udziału sektora prywatnego w realizacji projektów inwestycyjnych, ale również większego zaangażowania tego sektora w świadczenie usług publicznych. Na podkreślenie zasługuje swoista deklaracja polityczno-programowa zawarta w przywołanym dokumencie, zgodnie z którą „Rząd Polski jest zainteresowany dynamicznym rozwojem wykorzystania formuły PPP dla realizacji infrastruktury publicznej oraz świadczeniem wysokiej jakości usług publicznych. Partnerstwo publiczno-prywatne powinno być rozważane przez jednostki sektora publicznego jako alternatywna, równoważna z tradycyjnymi metoda realizacji zadań publicznych”.

Przyjęciu „Polityki Rządu...” towarzyszył przedłożony przez ministra rozwoju i finansów projekt nowelizacji obowiązującej ustawy o partnerstwie publiczno-prywatnym,

59 A. Pronińska, Termomodernizacje na fali PPP, „Puls Biznesu” 13.08.2013, https://www.pb.pl/termomodernizacje-na-fali-ppp-726066 [dostęp 24.06.2018].

60 https://www.ppp.gov.pl/Aktualnosci/Documents/2018_03_20_baza_danych_zamierzenia_PPP_kontakty.xlsx [dostęp 24.06.2018].

61 https://www.mr.gov.pl/strony/aktualnosci/polityka-ppp-przyjeta-przez-rzad/ [dostęp 28.02.2018]. 
który w marcu 2018 r. został przekazany do Sejmu ${ }^{62}$. Projekt ten nie przewiduje zmian w zakresie form realizacji zadań oświatowych, tj. nie stwarza możliwości zakładania i prowadzenia szkół w formule PPP. Jak dotychczas, dopuszczalne będzie realizowanie inwestycji oświatowych z wykorzystaniem zasobów i z rozłożeniem ryzyka na partnera prywatnego. $\mathrm{W}$ odniesieniu do sektora szkolnictwa wyższego projekt zakłada dopuszczalność przeznaczenia części funduszu pomocy materialnej dla studentów i doktorantów na wynagrodzenie partnera prywatnego w projektach budowy, a następnie utrzymania i zarządzania stołówkami lub domami studenckimi. Nowością projektu ustawy jest także umożliwienie dotowania przez JST zadań inwestycyjnych związanych z realizacją zadań tej jednostki, a wykonywanych w ramach umów PPP przez podmioty prywatne działające dla zysku (obecnie możliwe jest dotowanie działalności jedynie podmiotów non-profit). Powyższe propozycje trudno uzasadnić w świetle deklarowanych celów projektu ustawy, tj. większej mobilizacji prywatnych środków finansowych do realizacji inwestycji celu publicznego.

\section{Podsumowanie i wnioski}

Bogata literatura przedmiotu unaocznia, że partnerstwo publiczno-prywatne w obszarze oświaty może przybierać wiele postaci. Omówione w opracowaniu formy PPP stanowią jedynie niewielki fragment badanego zjawiska. Idea partnerstwa publiczno-prywatnego oznacza szeroki wachlarz możliwości i wariantów realizacji usług oświatowych. Podmioty prywatne uczestniczą w wykonywaniu zadań oświatowych w celu zarobkowym bądź filantropijnie, na zasadach stałych bądź okazjonalnych. Udział partnera prywatnego może dotyczyć budowy obiektów szkolnych, zarządzania nimi i ich utrzymywania, remontów i napraw, świadczenia usług towarzyszących i pomocniczych (dowożenie do szkól, wyżywienie uczniów w szkołach, prowadzenie zajęć dodatkowych), kształcenia i doskonalenia nauczycieli, opracowywania programów nauczania i podręczników. Najbardziej typową i najpowszechniej wykorzystywaną formą partnerstwa publiczno-prywatnego w edukacji jest prowadzenie szkół i placówek oświatowych przez podmiot niepubliczny, współfinansowane ze środków publicznych.

Doświadczenia państw takich jak Wielka Brytania unaoczniają, że formuła partnerstwa publiczno-prywatnego w świadczeniu usług oświatowych nie zawsze okazuje

62 Druk sejmowy nr 2333, http://www.sejm.gov.pl/sejm8.nsf/PrzebiegProc.xsp?nr=2333 [dostęp 24.06.2018]. 
się efektywna ekonomicznie dla sektora publicznego. W krótkim okresie pozwala ona na obejście restrykcji zadłużenia publicznego, niemniej całościowy bilans wypada opłacalnie z reguły dla partnera prywatnego, a korzyść podatnika jest dyskusyjna. Początkowe stadia realizacji polskich projektów inwestycji oświatowych nie pozwalają jeszcze na sformułowanie miarodajnych ocen. Jako najpoważniejsze wyzwanie przy realizacji wszelkich projektów PPP jawi się równomierne rozłożenie ryzyka na partnerów oraz należyte zabezpieczenie interesu publicznego w zawieranych kontraktach.

\section{Public-private partnership as a form of providing public services in education}

The text discusses the context and background for development of public-private partnership in the education sector. This development is based in the concept of New Public Management (New Governance) widespreaded in the policy and practice of governments since $1980 \mathrm{~s}$. The article discuses an example of involvement of non-public actors in providing education: The Private Financial Initiative (PFI). PFI has become the predominant model for building and operating of new schools in the United Kingdom. The British experiences have been employed by other countries as the number and volume of educational investments conducted in the PPP formula is steadily growing. This process has been illustrated by the relevant European Investment Bank data. The text also features the Polish approach to contracting out public education services i.e. when local authorities entrusts the operation of public school to a private entity. This concept corresponds with the idea of community schools where local communities become authentic owners of the school itself and its assets.

Keywords: public-private partnership, New Public Management, education services, education investments, community schools

\section{Literatura}

1. A new approach to public private partnerships, HM Treasury, December 2012.

2. Aritua B., Smith N.J., Athiyo R., Private finance for the delivery of school projects in England, „Management, Procurement and Law” 161 (MP4), 2008, s. 141-146.

3. Augustyńska B., Koncepcja partnerstwa publiczno-prywatnego na przykładzie Holandii, „Zarządzanie Publiczne” 3, 2007, „Zeszyty Naukowe ISP UJ”, s. 145-153. 
4. Bajerski A., Błaszczyk A., Likwidacja szkół podstawowych na wsi: perspektywa władz lokalnych, nauczycieli, rodziców, uczniów i pozostałych mieszkańców, „Przegląd Badań Edukacyjnych - Educational Studies Review" nr 21(20), 2015, s. 81-105.

5. Barak-Erez D., The Privatization Continuum, [w:] Private security, public order: the outsourcing of public services and its limits, red. S. Chesterman, A. Fisher, Oxford University Press, Oxford-New York 2009.

6. Biuletyn partnerstwa publiczno-prywatnego. Dobre praktyki, PARP, Warszawa 2015.

7. Blank M.J., Melaville A., Shah B.P., Making the Difference: Research and Practice in Community Schools, Coalition for Community Schools, Institute for Educational Leadership, Washington, D.C. 2003.

8. Blomgren Bingham L., Nabatchi T., O'Leary R., The New Governance: Practices and Processes for Stakeholder and Citizen Participation in the Work of Government, „Public Administration Review” Vol. 65, No. 5, September/October 2005.

9. Bray M., Community Partnerships in Education: Dimensions. Variations and Implications, Thematic Studies, Education for all 2000 Assessment, World Education Forum Dakar, Senegal, 26-28.04.2000, UNESCO, Paris 2001.

10. Bruns B., Filmer D., Patrinos H.A., Making Schools Work. New Evidence on Accountability Reforms, The World Bank, Washington, D.C. 2011.

11. Building schools for the future. Consultation on a new approach to capital investment, Department for Education and Skills, Annesley, Nottinghamshire 2003.

12. The Building Schools for the Future Programme. Renewing the secondary school estate, Report by The Comptroller and Auditor General, HC 135 Session 2008-2009, National Audit Office, London, 12.02.2009.

13. Chitty C., Education Policy in Britain, Palgrave-Macmillan, New York 2014.

14. Chleboś A., Analiza skuteczności postępowań ogłoszonych w ramach partnerstwa publiczno-prywatnego w wybranych sektorach, „Zeszyty Naukowe Politechniki Poznańskiej” nr 64, „Organizacja i Zarządzanie” 2015, s. 15-30.

15. Cieślak R., Liżewski M., Partnerstwo publiczno-prywatne w edukacji i szkolnictwie wyższym, „Gazeta Samorządu i Administracji” 20.01.2014, s. 48-49.

16. Contesting Neoliberal Education: Public Resistance and Collective Advance, red. D. Hill, Routledge, London 2009.

17. Corner D., The United Kingdom Private Finance Initiative: The Challenge of Allocating Risk, „OECD Journal on Budgeting” Vol. 5, No. 3, 2006.

18. Datablog: Counting the cost of school PFI schemes, Centre for Health and the Public Interest, February 2018.

19. Daviet B., Revisiting the Principle of Education as a Public Good, Education Research and Foresight Working Papers, UNESCO, July 2016.

20. Decentralizacja oświaty, red. M. Herbst, „Biblioteczka Oświaty Samorządowej” t. 7, Ośrodek Rozwoju Edukacji, Warszawa 2012. 
21. DeYoung A.J., Howley C.B., The Political Economy of Rural School Consolidation, „Peabody Journal of Education” Vol. 67, No. 4, „A Look at Rural Education in the United States" Summer 1990, s. 63-89.

22. Dziemianowicz-Bąk A., Dzierzgowski J., Likwidacja szkół podstawowych oraz przekazywanie stowarzyszeniom. Kontekst, proces i skutki przemian edukacyjnych w społecznościach lokalnych na podstawie analizy studiów przypadku, Instytut Badan Edukacyjnych, Warszawa 2014.

23. Fijor J.M., Czy dobra publiczne sq naprawdę publiczne?, „Studia Ekonomiczne” nr 1 (LXVIII), 2011, s. 87-100.

24. Financing Schools in Europe: Mechanisms, Methods and Criteria in Public Funding, Eurydice Report, European Commission/EACEA/Eurydice, Publications Office of the European Union, Luxembourg 2014.

25. Furmankiewicz M., Współpraca międzysektorowa $w$ ramach „partnerstw terytorialnych" na obszarach wiejskich w Polsce, „Studia Regionalne i Lokalne” nr 2(24), 2006, s. $117-136$.

26. Hellowell M., Price D., Pollock A.M., The use of Private Finance Initiative (PFI) Public Private Partnerships (PPPs) in Northern Ireland, University of Edinburgh, Northern Ireland Public Service Alliance 2008.

27. Hiszpanie będa niańczyć w PPP, „Puls Biznesu” 29.10.2012.

28. Holcombe R.G., A Theory of the Theory of Public Goods, „Review of Austrian Economics" Vol. 10, No. 1, 1997, s. 1-22.

29. Hood Ch., A public management for all seasons?, „Public Administration” Vol. 69, Spring 1991, s. 3-19.

30. Lane J.E., New Public Management: An Introduction, Routledge, New York 2002.

31. Klijn E.H., Public Private Partnership: deciphering meaning, message and phenomenon, [w:] International Handbook of PPP, red. G. Hodge, C. Greve, Edgar Elgar, Cheltenham 2010, s. 68-80.

32. Kopańska A., Partnerstwo publiczno-prywatne - wzory brytyjskie. Czego możemy się $z$ nich nauczyć, „Studia Regionalne i Lokalne” nr 3(25), 2006, s. 83-98.

33. Kozińska-Bałdyga A., Małe Szkoły - jak to było, „Mała szkoła - wielka szansa, VII Forum Inicjatyw Oświatowych”, Sejm, 2-3.12.2000.

34. Lane J.E., New Public Management: An Introduction, Routledge, New York 2002.

35. Lessons from PFI and other projects, National Audit Office, London, 28.04.2011.

36. Levin H.M., The Public-Private Nexus in Education, „The American Behavioral Scientist" Vol. 43, No. 1, September 1999, s. 124-137.

37. McCabe B., McKendrick J., Keenan J., PFI in Schools -Pass or Fail?, „Journal of Finance and Management in Public Services" Vol. 1, Summer 2001.

38. McLaughlin K., Ferlie E., Osborne S.P., New Public Management: Current Trends and Future Prospects, Routledge, New York 2005. 
39. Na ratunek likwidowanym szkołom, Forum_Od Nowa, 16.09.2014.

40. Opracowanie i upowszechnienie innowacyjnego modelu kontraktowania przez gminy usług społecznych w zakresie edukacji podstawowej, „Zeszyty Senackie” 17, 2013.

41. Partnerstwo publiczno-prywatne, red. G. Gołębiowski, K. Marchewka-Bartkowiak, „Studia BAS” nr 3(39), 2014.

42. Patrinos H.A., Barrera-Osorio F., Guáqueta J., The Role and Impact of Public-Private Partnerships in Education, The World Bank, Washington, D.C. 2009.

43. PFI and PF2, Report by the Comptroller and Auditor General, National Audit Office, 18.01.2018.

44. Pickard J., Plimmer G., Labour party threatens to nationalise PFI contracts, „Financial Times" 25.09.2017.

45. Problem likwidacji szkół. Komunikat z badań, Centrum Badania Opinii Społecznej, Warszawa, styczeń 2009.

46. Robertson S.L., Verger A., Governing Education Through Public Private Partnerships, published by the Centre for Globalisation, Education and Societies, University of Bristol 2012.

47. Rutkowska S., Mały cud oświatowy - rola stowarzyszeń rozwoju wsi w przejmowaniu i prowadzeniu małych szkół (przykład województwa kujawsko-pomorskiego), „Chowanna" 1, 2015, s. 77-90.

48. School-Community Partnerships in Australian Schools, Australian Council for Educational Research, November 2010.

49. Shaoul J., Stafford A., Stampleton P., Accountability for public expenditure under "Building Schools for the Future", [w:] Education, Capitalism and the Global Crisiss, red. S.J. Ball, M. Maguire, I.F. Goodsons, Routledge-Taylor\&Francis, London-New York 2012.

50. Stiglitz J.E., The Demand for Education in Public and Private School Systems, „Journal of Public Economics" 3, 1974, s. 349-385.

51. Turek M., Rola lokalnych grup działania w zarzaddzaniu rozwojem lokalnym na przykładzie małopolskich LGD w perspektywie finansowej 2007-2013, „Zarządzanie Publiczne" nr 4(24), 2013.

52. Wawrzyniak M., Partnerstwo publiczno-prywatne jako metoda realizacji przedszkoli $i$ żłobków przez gminy, „Biuletyn partnerstwa publiczno-prywatnego. Dobre praktyki”, Polska Agencja Rozwoju Przedsiębiorczości, Warszawa 2015.

53. Wettenhall R., The Rhetoric and Reality of Public-Private Partnerships, „Public Organization Review: A Global Journal" No. 3, 2003, s. 77-107.

54. Williams D. Terry, The Rural Solution. How Community Schools Can Reinvigorate Rural Education, Rural School and Community Trust, September 2010.

55. Włodarczyk B., Ekonomiczne i prawne bariery rozwoju partnerstwa publiczno-prywatnego w Polsce, „Optimum. Studia Ekonomiczne” nr 1(61), 2013. 
56. Wojtczak T., PPP szansą na nowe żłobki i przedszkola, „Bankier” 21.06.2011.

57. Wolf J., Kane E., Strickland B., Planning for Community Participation in Education, Prepared for the Office of Sustainable Development Bureau for Africa, U.S. Agency for International Development, Washington, D.C., February 1997.

58. Yescombe E.R., Public-Private Partnerships: Principles of Policy and Finance, Elsevier Finance, Butterworth-Heinemann, Oxford 2007.

59. Zalewski A., Reformy sektora publicznego w duchu nowego zarzadzania publicznego, [w:] Nowe zarządzanie publiczne w polskim samorzadzie terytorialnym, red. A. Zalewski, Oficyna Wydawnicza SGH, Warszawa 2007, s. 11-73.

\section{Akty prawne}

1. Rozporządzenie Ministra Edukacji Narodowej z dnia 15 grudnia 2017 r. w sprawie sposobu podziału części oświatowej subwencji ogólnej dla jednostek samorządu terytorialnego w roku 2018, DzU poz. 2395.

2. Ustawa z dnia 13 listopada 2003 r. o dochodach jednostek samorządu terytorialnego, DzU 2017, poz. 1453.

3. Ustawa $\mathrm{z}$ dnia 19 marca 2009 r. o zmianie ustawy o systemie oświaty oraz o zmianie niektórych innych ustaw, DzU 2009, nr 56, poz. 458 z późn. zm.

4. Ustawa z dnia 20 lutego 2015 r. o rozwoju lokalnym z udziałem lokalnej społeczności, DzU 2015, poz. 37 z późn. zm.

5. Ustawa z dnia 14 grudnia 2016 r. - Prawo oświatowe, DzU 2018, poz. 996.

6. Ustawa z dnia 27 października 2017 r. o finansowaniu zadań oświatowych, DzU poz. 2203. 